\title{
KARAKTERISTIK FISIKOKIMIA TEPUNG PANDAN TIKAR (Pandanus tectorius Park.)
}

\author{
[Physicochemical Characteristics of Flour Pandan Tikar (Pandanus tectorius Park.)]
}

\author{
Nelci Welmina Menanti ${ }^{1)}$, Zita Letviany Sarungallo²), Budi Santoso ${ }^{2 *}$ \\ 1) Alumni Jurusan Teknologi Hasil Pertanian, Fakultas Teknologi Pertanian, Universitas Papua (98314) \\ 2)Jurusan Teknologi Hasil Pertanian, Fakultas Teknologi Pertanian, Universitas Papua (98314) \\ *email korespondensi: budsandida@yahoo.com
}

Diterima 15 Januari 2021 / Disetujui 1 Maret 2021

\begin{abstract}
Pandan tikar (Pandanus tectorius Park.) is one of pandanaceae that spread almost along the Pacific coast, contains high nutrients, variety in fruit colors and has a distinctive pandan flavor. Fruit of Pandan tikar is potentially to be processed into flour. This research aims was to determine the physicochemical characteristic of flour fruit of pandan tikar. The results showed that the color of the flour varies from yellow to orange-red, the density of 0,27$0,22 \%$; solubility in water $52,58-61,65 \%$; the temperature of the gelatinization of $89{ }^{\circ}-91^{\circ} \mathrm{C}$; water content $10,97-$ $11,21 \%$; ash 5,59-6,54\%; fat 0,91-1,6\%; protein 3,62-3,8\%; carbohydrates 88,48-88,75\%; as well as crude fiber 20, 98-21,47\%; starch content 10,76-23,20\%; $\beta$-carotene 58,87-226,6 ppm; and total sugar 26,23-36,08\%.
\end{abstract}

Keywords: Physic properties, chemistry properties, flour, pandan tikar

\section{ABSTRAK}

Pandan tikar (Pandanus tectorius Park.) merupakan salah satu jenis pandanaceae yang penyebarannya hampir di sepanjang pantai pasifik, mengandung zat gizi yang cukup tinggi, memiliki variasi jenis dengan warna buah yang berbeda dan memiliki citarasa khas pandan. Buah pandan tikar sangat berpotensi untuk diolah menjadi tepung. Penelitian ini bertujuan untuk menentukan sifat fisik dan kimia tepung dari 3 jenis buah pandan tikar dengan warna kuning, kuning tua, dan oranye. Hasil penelitian menunjukkan bahwa tepung yang dihasilkan dari ketiga jenis buah pandan tikar memiliki dari warna kuning hingga merah-oranye; densitas kamba 0,27-0,33\%; kelarutan dalam air 57,58-61,65\%; suhu gelatinisasi $89^{\circ}-91^{\circ} \mathrm{C}$; kadar air 10,97-11,21\%; abu 5,59-6,54\%; lemak 0,91-1,6\%; protein 3,62-3,8; karbohidrat 88,48-88,75; serta kasar 20,98-21-47\%; kadar pati 10,76-23,20; $\beta$-karoten 58,87-226,6 3 ppm; dan total gula $26,23-36,08 \%$.

Kata kunci: Sifat fisik, sifat kimia, tepung, pandan tikar

\section{PENDAHULUAN}

Buah pandan tikar (Pandanus tectorius Park.) merupakan salah satu jenis pandan yang menyebar hampir di sepanjang pantai tropis, seluruh daerah Asia hingga ujung timur Asia yakni Daratan-daratan Kepulauan Pasifik, termasuk di Provinsi Papua Barat dengan keragaman yang cukup tinggi (Forbes dan Broadhead, 2007). Secara umum pandan tikar memiliki beberapa jenis yang dapat dibedakan berdasarkan warna buah yang bervariasi dari kuning, oranye hingga merah, namun seluruh jenis tersebut memiliki rasa buah yang sama yaitu manis asam (Thomsom et al., 2006). Pandan tikar banyak dimanfaatkan untuk berbagai keperluan manusia. Di Papua Nugini dan Salomon buah pandan tikar dikonsumsi dalam bentuk segar atau diolah, tetapi dari seluruh bagian tanaman, bagian daun yang paling banyak dimanfaatkan (Thomsom et al., 2006).

Buah pandan tikar, yang berasal dari Pulau Mansinam, pada tingkat kematangan agak matang memiliki kandungan gizi yaitu protein $(4,30 \%)$, lemak $(0,36 \%)$, abu $(5,45 \%)$, karbohidrat $(89,88 \%)$, serat kasar $(25,95 \%)$, dan total gula $(31,60 \%)$ serta $\beta$-karoten $(26,49$ ppm) (Sarungallo et al., 2018). Tingginya kadar karbohidrat pada daging buah pandan tikar sangat berpotensi untuk diolah menjadi tepung. Namun daging buah pandan tikar mudah mengalami pencokelatan enzimatis jika kontak dengan udara selama proses pembuatan tepung. Paiki et al., (2018) melaporkan pembuatan tepung buah pandan tikar dengan perlakuan blansing dapat menghasilkan tepung dengan warna yang lebih 
cerah dan mengandung gizi yang lebih baik dibandingkan perlakuan perendaman dengan asam sitrat dan tanpa perlakuan (kontrol).

Seperti telah disebutkan sebelumnya bahwa dari hasil penelitian Thomson et al. (2006) ditemukan ada beberapa jenis pandan tikar yang dibedakan dari warna daging buahnya. Variasi jenis yang sama pula ditemukan oleh Maker et al. (2018) di Provinsi Papua Barat; termasuk di Kabupaten Manokwari pada beberapa habitat tempat tumbuh (Sarungallo et al., 2018). Ditambahkan pula bahwa setiap jenis buah mempunyai komposisi yang berbeda, yang dapat dipengaruhi oleh beberapa faktor yaitu varietas/jenis, keadaan iklim tempat tumbuh, pemeliharaan tanaman, cara pemanenan, tingkat kematangan, waktu panen, dan kondisi penyimpanan (Muchtadi dan Ayustaningwarno, 2010). Perbedaan jenis dapat mempengaruhi karakteristik fisikokimia tepung buah pandan yang dihasilkan sehingga pemanfaatannya juga akan berbeda. Oleh karena itu, penelitian ini bertujuan untuk menentukan sifat fisik dan kimia tepung dari 3 jenis buah pandan tikar dengan warna kuning, kuning tua, dan oranye.

\section{BAHAN DAN METODE}

\section{Bahan dan Alat}

Bahan utama yang digunakan dalam penelitian ini adalah buah pandan tikar dari 3 jenis yang dibedakan berdasarkan warna buahnya yaitu kuning tua, oranye dan kuning (Gambar 1).
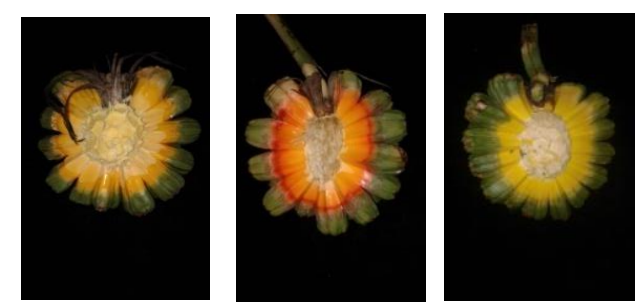

Gambar 1. Variasi warna tiga jenis buah pandan yaitu kuning tua, oranye dan kuning (dari kiri ke kanan).

Sampel buah yang digunakan berasal dari Pulau Mansinam Kabupaten Manokwari, Provinsi Papua Barat. Bahan kimia untuk analisis yang digunakan adalah amilum, iod, asam sulfat pekat, kalium sulfat, natrium hidroksida, natrium tiosulfat, asam borat jenuh, asam klorida, metal biru, metal merah, dietil eter, natrium klorida.

Alat-alat yang digunakan terdiri dari: 1 ) alat untuk pembuatan tepung yaitu oven pengering, pisau, blender, ayakan 80 mesh, aluminium foil, kertas label. 2) alat untuk analisis sifat fisikokimia tepung yaitu: timbangan analitik, thermometer, oven, desikator, corong buncen, peralatan gelas, penjepit, pipet tetes dan cawan.

\section{Metode Penelitian}

Penelitian ini menggunakan metode eksperimen dengan Rancangan Acak Lengkap (RAL) pada pengamatan fisikokimia tepung dari tiga jenis buah pandan tikar yang dibedakan berdasarkan warna buah yaitu kuning tua, oranye, dan kuning. Setiap perlakuan diulang sebanyak 3 ulangan.

\section{Pembuatan Tepung Buah Pandan Tikar}

Pembuatan tepung buah pandan tikar dilakukan dengan tahapan sortasi, pencucian, pengirisan, blansing yang dilakukan dengan mengukus irisan buah pada selama 3 menit, selanjutnya dikeringkan. Pengeringan menggunakan oven (suhu $60^{\circ} \mathrm{C}$ ) selama \pm 3 jam (yang ditandai dengan irisan yang dikeringkan mudah dipatahkan). Setelah kering, irisan kering buah pandan tikar dihaluskan dan diayak menggunakan ayakan 80 mesh dan dikemas (Paiki et al., 2018).

\section{Analisis Sifat Fisik Tepung}

Analisis sifat fisik tepung meliputi warna (Chromameter) (Sihombing, 2007), viskositas (Fardiaz et al., 1992), suhu gelatinisasi (Sudarmadji et al., 1997), kelarutan dalam air (Sathe dan Salunkhe, 1981) dan densitas kamba (Muchtadi dan Ayustaningwarno, 2010).

\section{Analisis Sifat Kimia Tepung}

Analisis sifat kimia tepung meliputi kadar air (AOAC, 2005), kadar abu (AOAC, 2005), kadar lemak (AOAC, 2005), kadar protein (AOAC, 2005), karbohidrat (by different), serat kasar (AOAC, 2005), kadar pati (AOAC, 2005), 
$\beta$-karoten (AOAC, 2005) dan total gula (AOAC, 2005).

\section{Analisis Data}

Data yang diperoleh dari hasil penelitian ini dianalisis secara statistik menggunakan Analisis Ragam pada tingkat kepercayaan $95 \%$ dan jika terdapat perbedaan nyata maka dilanjutkan dengan analisis DMRT (Duncan Multiple Range Test). Seluruh analisis statistik dilakukan menggunakan Statistical Analysis Software (SAS) Program 9.1.3. Data hasil penelitian ditampilkan dalam bentuk tabel serta gambar dan dibahas secara deskriptif.

\section{HASIL DAN PEMBAHASAN}

\section{Karakteristik Fisik Tepung Buah Pandan Tikar}

Karakteristik sifat fisik dari ketiga jenis tepung yang dihasilkan meliputi warna, densitas kamba, kelarutan dalam air, dan suhu gelatinisasi Tabel 1.

\section{Warna}

Warna merupakan salah satu komponen yang sangat penting dalam menentukan kualitas atau tingkat penerimaan suatu bahan pangan. Umumnya penentuan mutu suatu bahan pangan bergantung pada warna, karena warna yang paling dominan untuk dilihat terlebih dahulu (Winarno, 2009). Secara visual, tepung dari tiga jenis buah pandan tikar memiliki warna yang berbeda mulai dari kuning, kuning tua dan oranye (Gambar 2).
Hasil pengukuran warna tepung dari tiga jenis buah pandan tikar diperoleh tiga nilai yang diubah menjadi tiga notasi warna yaitu $L$, a dan b. Nilai $L$ merupakan nilai yang menunjukkan tingkat kecerahan, dimana semakin besar nilai L maka warna sampel semakin cerah sebaliknya semakin kecil nilai L maka akan semakin gelap (Pardede et al., 2017). Data pada Tabel 1 menunjukkan bahwa tingkat kecerahan (nilai L) tepung dari tiga jenis buah pandan tikar bervariasi berkisar antara 68,16-76,60.

Hasil analisis ragam menunjukkan bahwa jenis buah pandan tikar berpengaruh nyata $(P<0,05)$ terhadap tingkat kecerahan (nilai L) tepung yang dihasilkan. Hasil uji lanjut Duncan memperlihatkan bahwa tingkat kecerahan (nilai $\mathrm{L}$ ) tepung dari buah warna kuning $(76,60)$ paling tinggi berbeda nyata dengan tepung dari buah warna kuning tua $(74,95)$ dan tepung dari buah warna oranye $(68,16)$. Perbedaan ini dipengaruhi oleh nilai a dan nilai $b$ dimana jika nilai a tinggi, nilai $b$ rendah maka tingkat kecerahan tepung akan menurun atau kusam (merah) sebaliknya jika nilai a rendah dan nilai $b$ tinggi maka tepung yang dihasilkan lebih cerah (Tabel 1). Selain itu juga dipengaruhi oleh tingginya kandungan $\beta$ karoten (Tabel 2). Hasil penelitian ini yaitu pada buah yang berwarna kuning, relatif sama dengan laporan Paiki et al., (2018) bahwa nilai kecerahan ( $L$ ) tepung pandan tikar, dengan warna daging buah kuning, dengan perlakuan blansing sebesar 76,3 .

Tabel 1. Sifat Fisik Tepung dari Tiga Jenis Buah Pandan Tikar

\begin{tabular}{|c|c|c|c|}
\hline \multirow{2}{*}{ Parameter } & \multicolumn{3}{|c|}{ Warna Tepung Buah Pandan Tikar } \\
\hline & Kuning Tua & Oranye & Kuning \\
\hline \multicolumn{4}{|l|}{ Warna (nilai Hunter) } \\
\hline Nilai L (Kecerahan) & $74,95 \pm 0,11^{b}$ & $68,16 \pm 0,04 a$ & $76,60 \pm 0,17 c$ \\
\hline Nilai a (Kemerahan) & $4,13 \pm 0,06 a$ & $14,25 \pm 0,08 c$ & $4,72 \pm 0,13^{b}$ \\
\hline Nilai b (Kekuningan) & $35,05 \pm 0,07 \mathrm{~b}$ & $34,62 \pm 0,09 a$ & $35,40 \pm 0,16 c$ \\
\hline Densitas Kamba (g/ml) & $0,30 \pm 0,02^{a b}$ & $0,33 \pm 0,00^{b}$ & $0,27 \pm 0,00^{a}$ \\
\hline Kelarutan Dalam Air (\%) & $57,58 \pm 1,14 a$ & $60,39 \pm 0,64 b$ & $61,65 \pm 0,47 b$ \\
\hline Suhu Gelatinisasi $\left({ }^{\circ} \mathrm{C}\right)$ & $89 \pm 0,00 \mathrm{a}$ & $91 \pm 0,57 \mathrm{~b}$ & $90 \pm 0,00$ a \\
\hline
\end{tabular}




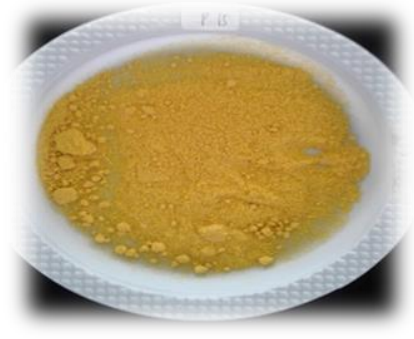

(a)

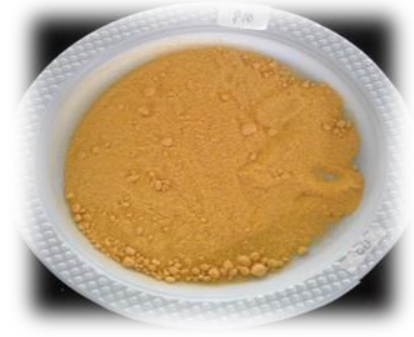

(b)

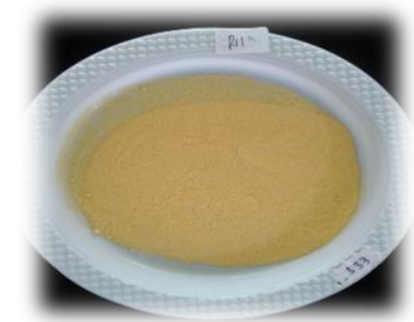

(c)

Gambar 2. Tiga jenis tepung dari buah pandan tikar yang dibedakan berdasarkan warna buah (a) kuning tua, (b) oranye, (c) kuning

Nilai a menunjukkan tingkat kemerahan, dimana semakin besar nilai a maka warna produk semakin merah (gelap) sebaliknya semakin kecil nilai a maka warna produk semakin terang (Pardede et al., 2017). Data padaTabel 1 menunjukkan bahwa tingkat kemerahan (nilai a) tepung dari tiga jenis buah pandan tikar berkisar antara 4,13-14,25.

Hasil analisis ragam menunjukkan bahwa jenis buah pandan tikar berpengaruh nyata $(P<0,05)$ terhadap tingkat kemerahan (nilai a) tepung yang dihasilkan. Hasil uji lanjut Duncan memperlihatkan bahwa tingkat kemerahan (nilai a) tepung dari tiga jenis buah pandan tikar berbeda nyata satu sama lain. Tingkat kemerahan (nilai a) tepung dari buah warna oranye $(14,25)$ paling tinggi berbeda nyata dari kedua jenis tepung lainnya. Warna tepung buah pandan tikar ini dipengaruhi oleh kandungan $\beta$-karoten buah, sebagai pigmen alaminya. Sarungallo et al., (2018) melaporkan kadar $\beta$-karoten buah pandan tikar agak matang berkisar $12,76-26,45$ ppm, tergantung jenis buahnya. Data pada Tabel 2 memperlihatkan bahwa kandungan tertinggi karotenod dimiliki tepung dari buah warna oranye dengan nilai a lebih tinggi dibandingkan tepung dengan warna kuning dan kuning tua.

Nilai b menunjukkan tingkat kekuningan, dimana semakin tinggi nilai $b$ maka warna sampel semakin kuning sebaliknya semakin rendah nilai b maka warna kuning akan semakin berkurang (Pardede et al., 2017). Data pada Tabel 1 menunjukkan bahwa tingkat kekuningan (nilai b) tepung dari tiga jenis buah pandan tikar berkisar antara 34,62-35,40. Hasil analisis ragam menunjukkan bahwa jenis buah pandan tikar berpengaruh nyata $(P<0,05)$ terhadap tingkat kekuningan (nilai b) tepung yang dihasilkan. Hasil uji lanjut Duncan memperlihatkan bahwa tingkat kekuningan (nilai b) tepung dari jenis buah warna kuning $(35,40)$ paling tinggi berbeda nyata dengan tepung dari buah warna oranye $(34,62)$ dan tepung dari buah warna kuning tua. Hal ini diduga dipengaruhi oleh kandungan $\beta$-karoten yang rendah sehingga menyebabkan nilai $b$ dari tepung warna kuning tinggi.

\section{Densitas Kamba}

Densitas kamba menunjukkan kepadatan partikel yang menempati sebuah ruang dengan volume tertentu, dimana semakin tinggi nilai densitas kamba menunjukkan produk semakin padat. Data pada Tabel 1 menunjukkan bahwa nilai densitas kamba tepung dari tiga jenis buah pandan tikar berkisar antara 0,27-0,33 g/ml.

Hasil analisis ragam menunjukkan bahwa jenis buah pandan tikar berpengaruh nyata $(P<0,05)$ terhadap nilai densitas kamba tepung yang dihasilkan. Hasil uji lanjut Duncan memperlihatkan bahwa densitas kamba tertinggi diperoleh pada tepung dari buah warna oranye yang tidak berbeda nyata dengan tepung dari buah warna kuning tua, namun berbeda nyata dengan tepung dari buah warna kuning. Salah satu faktor yang mempengaruhi densitas kamba yaitu adanya proses pengeringan. Seperti yang dilaporkan Erni et al., (2018) bahwa semakin lama pengeringan, densitas kamba tepung umbi talas semakin meningkat dari 0,67-0,75 g/ml. Dijelaskan pula bahwa pengeringan menyebabkan berkurangnya kadar air, sehingga bahan yang mengandung senyawa-senyawa seperi 
karbohidrat, protein dan mineral dalam konsentrasi yang lebih tinggi (Muchtadi dan Ayustaningwarno, 2010).

\section{Kelarutan Dalam Air}

Kelarutan dalam air menunjukkan bagaimana tingkat kemudahan suatu bahan dapat larut dalam air. Semakin tinggi nilai kelarutan dalam air maka semakin tinggi pula tingkat kemudahan suatu bahan untuk dapat larut dalam air (Prabasini et al., 2013). Data pada Tabel 1 menunjukkan bahwa nilai kelarutan tepung dari tiga jenis buah pandan tikar berkisar antara 57,58-61,65\%.

Hasil analisis ragam menunjukkan bahwa jenis buah pandan tikar berpengaruh nyata $(P<0,05)$ terhadap tingkat kelarutan tepung yang dihasilkan. Hasil uji lanjut Duncan memperlihatkan bahwa tingkat kelarutan tepung dari buah pandan warna kuning tertinggi $(61,65 \%)$ tidak berbeda nyata dengan tepung dari buah warna oranye, namun berbeda nyata dengan tepung dari buah warna kuning tua. Hal ini diduga karena tepung dari buah pandan tikar warna kuning rendah akan serat pangan yang tidak larut (Tabel 2) sehingga kelarutannya dalam air tinggi. Jika dibandingkan dengan hasil penelitian Paiki et al., (2018), tingkat kelarutan tepung dari buah pandan tikar dalam air sebesar 53,43\%. Perbedaan ini diduga disebabkan karena waktu blansing yang berbeda sehingga menyebabkan perbedaan tingkat kelarutannya.

\section{Suhu Gelatinisasi}

Suhu gelatinisasi merupakan salah satu proses dimana pati menjadi larut dalam air ketika disuspensi dipanaskan hingga suhu kritis tertentu (Emire et al., 2006). Data pada Tabel 1 menunjukkan bahwa suhu gelatinisasi tepung dari tiga jenis buah pandan tikar berkisar antara 89-91 ${ }^{\circ} \mathrm{C}$.

Hasil analisis ragam menunjukkan bahwa jenis buah pandan tikar berpengaruh nyata $(P<0,05)$ terhadap suhu gelatinisasi tepung yang dihasilkan. Hasil uji lanjut Duncan memperlihatkan bahwa suhu gelatinisasi tepung dari buah pandan tikar warna oranye $\left(91{ }^{\circ} \mathrm{C}\right)$ paling tinggi berbeda nyata dengan tepung dari dua jenis tepung pandan tikar lainnya, sementara suhu gelatinisasi terendah pada tepung dari buah pandan tikar warna kuning tua $\left(89^{\circ} \mathrm{C}\right)$. Suhu gelatinisasi dalam penelitian ini hampir sama dengan yang diperoleh oleh Paiki et al. (2018), yaitu berkisar antara $92,33^{\circ}-93^{\circ} \mathrm{C}$. Hal ini dikarenakan adanya kandungan serat kasar yang tidak larut dalam air tinggi sehingga menghambat proses terjadinya gelatinisasi.

\section{Kandungan Gizi Tepung Pandan}

Tepung yang telah dihasilkan dari tiga jenis buah pandan tikar yang dibedakan berdasarkan warna buah yaitu kuning tua, oranye dan kuning, memilih kandungan gizi yang terbaik. Hasil analisis proksimat (kadar air, abu, lemak, protein, karbohidrat), serat kasar, kadar pati, $\beta$-karoten dan total gula disajikan pada Tabel 2.

Air merupakan salah satu komponen yang paling penting dalam bahan makanan yang dapat mempengaruhi penampakan, tekstur serta cita rasa dari suatu produk. Kadar air atau banyaknya air yang terkandung dalam bahan dinyatakan dalam persen (Winarno, 2009). Data pada Tabel 2 menunjukkan bahwa kadar air tepung dari tiga jenis buah pandan tikar berkisar antara 10,97-11,36\% bk.

Hasil analisis ragam menunjukkan bahwa jenis buah pandan tikar berpengaruh nyata $(P<0,05)$ terhadap kadar air tepung yang dihasilkan. Hasil uji lanjut Duncan memperlihatkan bahwa kadar air tepung dari buah warna kuning $(11,36 \%)$ paling tinggi berbeda nyata dengan tepung dari buah warna kuning tua $(10,97 \%)$ dan tepung dari buah warna oranye $(11,21 \%)$. Pada kondisi rendahnya kadar air tersebut maka tepung pandan tikar lebih bersifat higroskopis yaitu lebih mudah menyerap uap air sehingga perlu dikemas dengan baik. Apabila terjadi penyerapan uap air maka akan menyebabkan tepung pandan tikar menggumpal sehingga akan menurunkan mutunya. 
Tabel 2. Kandungan Gizi Tepung dari Tiga Jenis Buah Pandan Tikar

\begin{tabular}{|c|c|c|c|}
\hline \multirow{2}{*}{ Parameter } & \multicolumn{3}{|c|}{ Warna Tepung Buah Pandan Tikar } \\
\hline & Kuning Tua & Oranye & Kuning \\
\hline Kadar Air (\%, bk) & $10,97 \pm 0,00^{a}$ & $11,21 \pm 0,01^{b}$ & $11,36 \pm 0,00 c$ \\
\hline Abu $(\%, b k)$ & $5,7 \pm 0,01^{b}$ & $6,54 \pm 0,00 c$ & $5,59 \pm 0,01^{a}$ \\
\hline Lemak (\%, bk) & $1,6 \pm 0,01 c$ & $1,20 \pm 0,02^{b}$ & $0,91 \pm 0,01^{a}$ \\
\hline Protein (\%, bk) & $3,8 \pm 0,00^{b}$ & $3,76 \pm 0,01^{b}$ & $3,62 \pm 0,03 a$ \\
\hline Karbohidrat (\%, bk) & $88,75 \pm 0,00^{b}$ & $88,48 \pm 0,00^{a}$ & $89,86 \pm 0,03 c$ \\
\hline Serat Kasar $(\%, b k)$ & $21,47 \pm 0,03^{b}$ & $21,01 \pm 0,01^{a}$ & $20,98 \pm 0,00 \mathrm{a}$ \\
\hline Kadar Pati $(\%$, bk) & $23,20 \pm 0,00 c$ & $10,76 \pm 0,00^{a}$ & $13,89 \pm 0,01^{b}$ \\
\hline$\beta$-karoten (ppm) & $144,9 \pm 26,09 \mathrm{~b}$ & $226,6 \pm 0,03 c$ & $58,87 \pm 1,2^{a}$ \\
\hline Total Gula (\%, bk) & $26,23 \pm 0,02^{\mathrm{a}}$ & $36,08 \pm 0,03 c$ & $33,84 \pm 0,03 b$ \\
\hline
\end{tabular}

Menurut Buckle et al., (1987) pada prinsipnya berbagai jenis tepung mempunyai sifat higroskopis sehingga mudah mengalami kerusakan akibat penyerapan air dari lingkungannya. Berdasarkan SNI 3751:2009 untuk kadar air tepung terigu yaitu 14,5\% maka tepung buah pandan tikar yang dihasilkan lebih rendah yaitu berkisar 10,97\%$11,36 \%$.

Kadar abu merupakan mineral yang sering disebut juga sebagai zat gizi anorganik, yang diperoleh dari sisa-sisa pembakaran bahan-bahan organik. Zat anorganik inilah yang disebut dengan abu (Poedjiadi dan Supriyanti, 2005). Data pada Tabel 2 menunjukkan bahwa kadar abu tepung dari tiga jenis buah pandan tikar berkisar antara 5,7-6,56 \% bk. Hasil analisis ragam menunjukkan bahwa jenis buah pandan tikar berpengaruh nyata $(P<0,05)$ terhadap kadar abu tepung yang dihasilkan. Hasil uji lanjut Duncan memperlihatkan bahwa kadar abu tepung dari buah pandan warna oranye $(6,54 \%)$ paling tinggi berbeda nyata dengan tepung dari buah warna kuning tua $(5,7 \%)$ dan tepung dari buah warna kuning. Sementara kadar abu terendah pada tepung warna kuning (5,59\%). Kadar abu dipengaruhi oleh banyaknya kandungan mineral yang terdapat dalam suatu bahan. Kandungan mineral paling tinggi pada tepung warna oranye sehingga kadar abunya tinggi begitu pula sebaliknya.

Lemak merupakan energi paling efektif dibandingkan karbohidrat dan protein. Winarno, (2009) menjelaskan bahwa untuk menghasilkan $9 \mathrm{kkal} / \mathrm{gram}$ hanya memerlukan sebanyak satu gram lemak, sedangkan untuk karbohidrat dan protein hanya menghasilkan 4 kkal/gram. Selain itu, lemak hampir terdapat pada semua bahan pangan dengan kandungan yang berbeda-beda. Data pada Tabel 2 menunjukkan bahwa kadar lemak tepung dari tiga jenis buah pandan tikar berkisar antara 0,91-1,20\% bk. Secara umum buah pandan tikar bukan merupakan sumber lemak, sehingga tepung yang dihasilkan memiliki kandungan kadar lemak yang sangat rendah. Hasil analisis ragam menunjukkan bahwa jenis buah pandan tikar berpengaruh nyata $(P<0,05)$ terhadap kadar lemak tepung yang dihasilkan. Hasil uji lanjut Duncan memperlihatkan bahwa kadar lemak tepung dari buah warna oranye $(1,20 \%)$ paling tinggi berbeda nyata dengan tepung dari buah warna kuning $(0,9 \%)$ dan tepung dari buah warna kuning tua $(1,6 \%)$, dan kadar lemak terendah pada tepung dari buah warna kuning.

Protein merupakan salah satu zat makanan yang penting bagi tubuh manusia yang berfungsi sebagai zat pembangun dan pengatur tubuh. Protein juga merupakan salah satu sumber-sumber asam amino (Winarno, 2009). Data pada Tabel 2 menunjukkan bahwa kadar protein tepung dari tiga jenis buah pandan tikar berkisar antara 3,62-3,8\% bk. Kadar protein tepung pandan tikar cukup tinggi sehingga dapat berpotensi terjadi pencoklatan (maillard) dalam proses pengolahannya (rekasi antara asam amino dan gula pereduksi). Oleh Karena itu perlakuan yang dilakukan untuk 
mengantisipasinya yaitu dengan perlakuan blanshing. Hasil analisis ragam menunjukkan bahwa jenis buah pandan tikar berpengaruh nyata $(P<0,05)$ terhadap kadar protein tepung yang dihasilkan. Hasil uji lanjut Duncan memperlihatkan bahwa kadar protein tepung dari buah warna kuning tua $(3,8 \%)$ tertinggi dan tidak berbeda nyata dengan tepung dari buah warna oranye, namun berbeda nyata dengan tepung dari buah warna kuning. Adanya perbedaan ini dipengaruhi oleh adanya kandungan protein yang mudah larut dalam air sehingga saat proses pencucian protein tersebut larut dalam air. Juga disebabkan oleh proses pengeringan seperti dijelaskan Winarno (2009) bahwa faktor-faktor yang menyebabkan terjadinya denaturasi protein antara lain panas, $\mathrm{pH}$, bahan kimia, mekanik dan sebagainya.

Karbohidrat merupakan salah satu sumber kalori utama yang berperan penting dalam menentukan karakterisasi bahan pangan seperti rasa, aroma, serta tekstur dan lain-lain (Winarno, 2009). Data pada Tabel 2 menunjukkan bahwa kadar karbohidrat tepung dari tiga jenis buah pandan tikar berkisar antara $88,48-89,86 \%$ bk. Hasil analisis ragam menunjukkan bahwa jenis buah pandan tikar berpengaruh nyata $(P<0,05)$ terhadap kadar karbohidrat tepung yang dihasilkan. Hasil uji lanjut Duncan memperlihatkan bahwa kadar karbohidrat tepung dari buah warna kuning $(89,86 \%)$ paling tinggi berbeda nyata dengan tepung dari buah warna oranye $(88,48 \%)$ dan tepung dari buah warna kuning tua. Kadar karbohidrat dipengaruhi oleh persentase komposisi gizi lainnya seperti kadar air, abu, lemak dan protein (Pardede et al., 2017).

Serat kasar merupakan residu dari bahan makanan atau pertanian setelah diperlakukan dengan asam dan alkali mendidih, dan terdiri dari selulosa dengan sedikit lignin dan pentosa (Fardiaz, 1984). Serat kasar sangat penting dalam penilaian kualitas bahan makanan tersebut. Data pada Tabel 2 menunjukkan bahwa serat kasar tepung dari tiga jenis buah pandan tikar berkisar antara $20,98-21,47 \%$ bk. Hasil analisis ragam menunjukkan bahwa jenis buah pandan tikar berpengaruh nyata $(P<0,05)$ terhadap serat kasar tepung yang dihasilkan. Hasil uji lanjut Duncan memperlihatkan bahwa kandungan serat kasar tepung dari buah warna kuning tua $(21,47 \%)$ paling tinggi berbeda nyata dengan tepung dari buah warna kuning (20,98\%) dan tepung dari buah warna oranye. Namun antara tepung dari buah warna kuning dan tepung dari buah warna oranye tidak berbeda nyata. Hal ini diduga karena tepung dari buah warna kuning mengandung serat yang tidak larut lebih tinggi dibanding kedua jenis pandan tikar lainnya.

Salah satu jenis karbohidrat yang banyak terdapat di alam, yang dapat diperoleh dari berbagai bagian tanaman seperti biji, akar, batang maupun sereal yaitu pati (Deka dan Siti, 2016). Data pada Tabel 2 menunjukkan bahwa kadar pati tepung dari tiga jenis buah pandan tikar berkisar antara 10,76-23,20\% bk.Hasil analisis ragam menunjukkan bahwa jenis buah pandan tikar berpengaruh nyata $(P<0,05)$ terhadap kadar pati tepung yang dihasilkan. Hasil uji lanjut Duncan memperlihatkan bahwa kadar pati tepung dari buah warna kuning tua $(23,20 \%)$ paling tinggi berbeda nyata dengan tepung dari buah warna oranye $(10,76 \%)$ dan tepung dari buah warna kuning $(13,39 \%)$. Sementara kadar pati terendah adalah tepung dari buah warna oranye. Hal ini diduga berkaitan dengan berbedanya jenis pandan tikar yang digunakan sehingga mempengaruhi kandungan patinya.

Data pada Tabel 2 menunjukkan bahwa total gula tepung dari tiga jenis buah pandan tikar berkisar antara 26,23-36,08\%. Hasil analisis ragam menunjukkan bahwa jenis buah pandan tikar berpengaruh nyata $(P<0,05)$ terhadap total gula tepung yang dihasilkan. Hasil uji lanjut Duncan memperlihatkan bahwa total gula tepung warna oranye $(36,08 \%)$ paling tinggi berbeda nyata dengan tepung warna kuning tua $(26,23 \%)$ dan tepung warna kuning (33,84\%). Adanya perbedaan total gula ini selain diduga karena perbedaan jenis, juga kemungkinan karena adanya sedikit perbedaan tingkat kematangan buah, hal ini karena penentuan tingkat kematangan buah dalam penelitian ini hanya secara visual. 


\section{KESIMPULAN}

Tepung yang dihasilkan dari tiga jenis pandan tikar memiliki warna kuning, warna oranye dan warna kuning tua, dengan kisaran densitas kamba antara 0,27-0,33\%, kelarutan dalam air antara $57,58-61,65 \%$, suhu gelatinisasi antara $89-91{ }^{\circ} \mathrm{C}$, kadar air antara $10,97-11,21 \%$ bk, abu antara 5,59-6,54\% bk, lemak antara $0,91-1,6 \% \mathrm{bk}$, protein antara $3,62-3,8 \%$ bk, karbohidrat antara 88,48$88,75 \%$ bk, serat kasar antara $20,98-21-47 \%$ bk, kadar pati antara 10,76-23,20 bk, $\beta$-karoten antara 58,87-226,6 ppm dan total gula antara $26,23-36,08 \%$ bk. Tepung yang terbaik adalah yang dihasilkan dari buah pandan tikar kuning tua karena memiliki kadar pati tertinggi serta suhu gelatinisasi dan total gula terendah.

\section{UCAPAN TERIMA KASIH}

Terima kasih kepada PT. Indofood yang telah mendanai penelitian ini melalui Program Indofood Riset Nugraha (IRN) Tahun 2018-2019.

\section{DAFTAR PUSTAKA}

AOAC (Association of Analytical Chemist). 2005. Official Methods of Analysis of AOAC International. $16^{\text {th }}$ edition. AOAC Inc. Washington DC., USA.

Buckle, K. A., Edwars R. A., Hileet G., dan Wootton M., 1987. Ilmu Pangan. UI Press. Jakarta.

Deka, D. and Siti, N., 2016. Dual Modification of Taro Starch by Microwave and Other Heatmoisture Treatments. International Journal of Biological Macromolecules. 92: 416-422.

DOI:

10.1016/j.ijbiomac.2016.07.040.

Emire, S.A., Meaza, M., and Rakshit, S.K. 2006. Physicochemical Properties, Pasting Behavior and Functional Characteristics of Flours and Starches from Improved Bean (Phaseolus vulgaris L.) Varieties Grown in East Africa. Agricultural Engineering International: The CIGR Ejournal. Manuscript FP 05 015. Vol. VIII. February, 2006.
Erni, N., Kardiman, R., dan Fadillah. 2018. Pengaruh Suhu dan Lama Pengeringan terhadap Sifat Kimia dan Organoleptik Tepung Umbi Talas (Colocasia esculanta). Jurnal Pendidikan Teknologi Pertanian 4: 95-105. DOI: doi.org/10.26858/jptp.v1i1.6223.

Fardiaz, D. 1984. Pemanfaatan Limbah Jeruk Sebagai Pembuatan Pektin. Jurusan Teknologi Pangan dan Gizi. Proyek Peningkatan atau Pengembangan Perguruan Tinggi, Institut Pertanian Bogor. Bogor.

Fardiaz, D., Andarwulan, N., Wijaya, H., dan Puspitasari, N. L. 1992. Teknik Analisis Sifat Kimia dan Fungsional Komponen Pangan. Departemen Pendidikan dan Kebudayaan. Direktorat Perguruan Tinggi. Pusat Antar Universitas Pangan dan Gizi. Institut Pertanian Bogor. Bogor.

Forbes, K. and Broadhead, J. 2007. The Role of the Mitigation of Tsunami Impacts. Food and Agriculture Organization of the United Nations, Florida. ISBN 978-97413-9321-3.

Maker, D., Sarungallo, Z. L., Santoso, B., Latumahina, R.M.M., Susanti, C, M, E., Sinaga, N. I., dan Irbayanti, D. N. 2018. Sifat Fisik, Kandungan Vitamin $\mathrm{C}$ dan Total Padatan Buah Pandan Tikar (Pandanus tectorius P.). Agritechnology, 1(1): 1-11. DOI: https://doi.org/10.51310/agritechn ology.v1i1.5

Muchtadi, T. R., dan Ayustaningwarno, F. 2010. Teknologi Proses Pengolahan Pangan. Penerbit Alfabeta, Bandung.

Paiki, S.N.P., Irman, Sarungallo, Z.L., Latumahina, R.M.M., Susanti, C. M. E, Sinaga, N, I., dan Irbayanti, D. N. 2018. Pengaruh Blansing dan Perendaman Asam Sitrat terhadap Mutu Fisik dan Kandungan Gizi Tepung Buah Pandan Tikar (Pandanus tectorius Park.), Agritechnolog.y 1(2): 76-83.

Pardede M. C., Julianti, E., dan Ridwansyah. 2017. Pengaruh Suhu Blansing dan Suhu Pengeringan Terhadap Mutu Fisik Tepung Ubi Jalar Ungu (Ipomea batatas L). Program Studi Ilmu dan Teknologi Pangan Fakultas Pertanian. Universitas Sumatera Utara. Medan. 
Poedjiadi, A. dan Supriyanti, F. M. T. 2005. Dasar-dasar Biokimia. UI-Press, Jakarta.

Prabasini, H., Ishartani, D., dan Rahadian, D. 2013. Kajian Sifat Kimia dan Fisik Tepung Labu Kuning (Cucurbita moschata) dengan Perlakuan Blansing dan Perendaman dalam Natrium Metabisulfit $\left(\mathrm{Na}_{2} \mathrm{~S}_{2} \mathrm{O}_{3}\right)$. Jurnal Teknosains Pangan. 2 (2): 93-102.

Sathe, S.K., and Salunkhe, D.K. 1981. Isolation, Partial Characterization and Modification of the Great Northern Bean (Phaseolus vulgaris L.). Journal of Food science. 46: 617-621. DOI: doi.org/10.1111/j.13652621.1981.tb04924.x.

Sarungallo, Z. L., Susanti, C. M. E., Sinaga, N. I., Irbayanti, D. N., dan Latumahina, R. M. M. 2018. Kandungan Gizi Buah Pandan Laut (Pandanus tectorius Park.) pada Tiga Tingkat Kematangan. Jurnal Aplikasi Teknologi Pangan. 7 (1):21-26. DOI: doi.org/10.17728/jatp.2577.

Sihombing, P. A. 2007. Aplikasi Ekstrak Kunyit (Curcuma domestica) sebagai Bahan Pengawet Mie Basah. Skripsi. Program Pasca Sarjana. Institut Pertanian Bogor. Bogor.

Sudarmadji, S., Bambang, H., dan Suhardi.1997. Prosedur Analisis untuk Bahan Makanan dan Pertanian. Liberty. Yogyakarta.

Thomson, L. A., Englberger, L., Guarino, L., Tha Man, R.R., and Elevitch, C.R. 2006. Pandanus tectorius, Permanent Agricultur Resources (PAR). HōlualoaHawai.

Winarno, F.G. 2009. Kimia pangan dan gizi. PT. Gramedia Pustaka Utama. Jakarta. 